\title{
Bacillus selenatarsenatis sp. nov., a selenate- and arsenate-reducing bacterium isolated from the effluent drain of a glass-manufacturing plant
}

Correspondence

Shigeki Yamamura

yshige@nies.go.jp
Selenium and arsenic, trace elements distributed widely in the Earth's crust, are required in trace amounts for growth and metabolism but are toxic at micromolar concentrations. In oxic environments, they occur primarily as the soluble oxyanions selenate $[\mathrm{Se}(\mathrm{VI})]$ and arsenate $[\mathrm{As}(\mathrm{V})]$. In anoxic environments, these oxyanions can be utilized by prokaryotes as terminal electron acceptors for anaerobic respiration. The selenate- and/or arsenate-respiring prokaryotes isolated to date are diverse both physiologically and phylogenetically and are not confined to one particular phylum (Oremland \& Stolz, 2000, 2003; Stolz et al., 2002). In general, oxyanions, including selenate and arsenate, are actively cycled and play an important role in carbon mineralization processes in certain environments.

tPresent address: Japan Agency for Marine-Earth Science and Technology, 2-15 Natsushima-cho, Yokosuka 237-0061, Japan.

The GenBank/EMBL/DDBJ accession number for the $16 \mathrm{~S}$ rRNA gene sequence of strain $\mathrm{SF}-1^{\top}$ is $\mathrm{AB} 262082$.

A figure showing a maximum-parsimony tree is available as supplementary material in IJSEM Online.
A Gram-positive, selenate-reducing bacterium was isolated from a selenium-contaminated sediment collected from an effluent drain that had been receiving selenium-containing discharge from a glass-manufacturing plant. The bacterium, designated strain SF-1 ${ }^{\mathrm{T}}$ (Fujita et al., 1997), is capable of respiring with selenate as a terminal electron acceptor and lactate as an electron donor. Selenate is reduced to elemental selenium via the intermediate selenite (Fujita et al., 1997; Kashiwa et al., 2000). A laboratory-scale continuous reactor using strain SF-1 $1^{\mathrm{T}}$ had been constructed to remove selenate and selenite from wastewater (Fujita et al., 2002). Our studies revealed that strain $\mathrm{SF}-1^{\mathrm{T}}$ also grew anaerobically when arsenate was present as an electron acceptor (Yamamura et al., 2003), and this ability for dissimilatory reduction of arsenate to arsenite could be utilized to extract arsenic from contaminated soil for the purpose of bioremediation (Yamamura et al., 2005). Based on physiological, phylogenetic and molecular evidence presented here, the strain represents a novel species of the genus Bacillus.

Strain SF- $1^{\mathrm{T}}$ was grown on a basal salt medium supplemented with $0.1 \%$ yeast extract ( $\mathrm{pH} 8.0$ ) as described by 
Yamamura et al. (2003). For aerobic growth, $10 \mathrm{~g}$ glucose $1^{-1}$ was used as the electron donor, whereas sodium lactate $(20 \mathrm{mM})$ was used instead of glucose for anaerobic growth with one of selenate, arsenate or nitrate $(1 \mathrm{mM})$ as the electron acceptor. Bacillus jeotgali JCM $10885^{\mathrm{T}}$, obtained from the RIKEN BRC-JCM, was cultivated on an appropriate medium (Yoon et al., 2001) or under the same condition as strain $\mathrm{SF}-1^{\mathrm{T}}$, except that the $\mathrm{pH}$ was adjusted to 7.5, for phenotypic comparison. Biochemical tests were carried out using API 20E and API 50CHB kits according to the instructions of the manufacturer (bioMérieux). To determine sensitivity to antibiotics, a culture of strain SF- $1^{\mathrm{T}}$ was inoculated onto LB agar plates $(\mathrm{pH} \mathrm{8.0)}$ containing kanamycin, tetracycline, chloramphenicol, ampicillin or erythromycin at $1-30 \mu \mathrm{g} \mathrm{ml}^{-1}$ and incubated at $37^{\circ} \mathrm{C}$ for 4 days. Fatty acid methyl esters were extracted and analysed following the standard protocol of the Sherlock Microbial Identification System (MIDI).

For genomic DNA isolation, strain SF- $1^{\mathrm{T}}$ and $B$. jeotgali JCM $10885^{\mathrm{T}}$ were grown aerobically in 1 litre batches to midexponential phase and cells were harvested by centrifugation at $8000 \mathrm{~g}\left(10 \mathrm{~min}, 4^{\circ} \mathrm{C}\right)$. Genomic DNA was prepared using the DNeasy Tissue kit or DNeasy Plant kit (Qiagen) according to the manufacturer's instructions.

The G $+\mathrm{C}$ content of the DNA was determined by HPLC as described previously (Katayama-Fujimura et al., 1984). DNADNA hybridization of strain SF- $1^{\mathrm{T}}$ and B. jeotgali JCM $10885^{\mathrm{T}}$ was carried out by the method of Ezaki et al. (1989).

Gene fragments specific to the 16S rRNA-encoding regions were amplified by PCR using primers 20F (5'-GAGTTTGATCCTGGCTCAG- ${ }^{\prime}$; positions 9-27) and 1500R (5'GTTACCTTGTTACGACTT-3'; positions 1509-1492) (Kawasaki et al., 1993). Positions in the 16S rRNA gene fragment are based on the Escherichia coli numbering system (GenBank accession no. V00348) of Brosius et al. (1981).
Amplified 16S rRNA genes were sequenced directly using the ABI PRISM BigDye Terminator cycle sequencing ready reaction kit and an ABI PRISM model 310 Genetic Analyzer (Applied Biosystems). The following primers were used for sequencing: 20F, 1500R, 520F (5'-CAGCAGCCGCGGTAATAC-3'; positions 519-536), 520R (5'-GTATTACCGCGGCTGCTG-3'; positions 536-519), 920F (5'-AAACTCAAATGAATTGACGG-3'; positions 907-926) and 920R (5'CCGTCAATTCATTTGAGTTT-3'; positions 926-907).

The 16S rRNA gene sequence of strain SF- $1^{\mathrm{T}}$ determined was compared with reference sequences using BLAST similarity searches (Altschul et al., 1997) and the closely related sequences were obtained from GenBank. Multiple alignments were generated and the calculation of distance matrices for the aligned sequences (Kimura, 1980) was carried out using CLUSTAL X (Thompson et al., 1997) and MEGA version 3.1 (Kumar et al., 2004). Phylogenetic trees were inferred using the neighbour-joining (Saitou \& Nei, 1987) and maximum-parsimony (Kluge \& Farris, 1969) methods. The phylogenetic tree topology was evaluated by bootstrap analysis with 1000 replicates (Felsenstein, 1985). Sequence similarity values were calculated using GENETYX version 8 (Genetyx Corporation).

Strain SF- $1^{\mathrm{T}}$ is a Gram-positive, oxidase-negative, catalasepositive, motile, spore-forming, facultatively anaerobic and rod-shaped bacterium (Fujita et al., 1997). Phylogenetic analysis based on the 16S rRNA gene sequence (1413 bp) of strain SF- $1^{\mathrm{T}}$ indicated that it fell within the low-G +Ccontent, Gram-positive, aerobic, spore-forming bacilli (Fig. 1 and Supplementary Fig. S1 available in IJSEM Online). The closest phylogenetic relative of strain SF-1 ${ }^{\mathrm{T}}$ was B. jeotgali JCM $10885^{\mathrm{T}}$, with a sequence similarity of $99.6 \%$; lower similarity was observed with some phylogenetically related Bacillus type strains, including Bacillus vireti LMG $21834^{\mathrm{T}}(96.7 \%)$, Bacillus novalis LMG $21837^{\mathrm{T}}$ (96.6\%), Bacillus drentensis LMG $21831^{\mathrm{T}}$ (96.5\%),

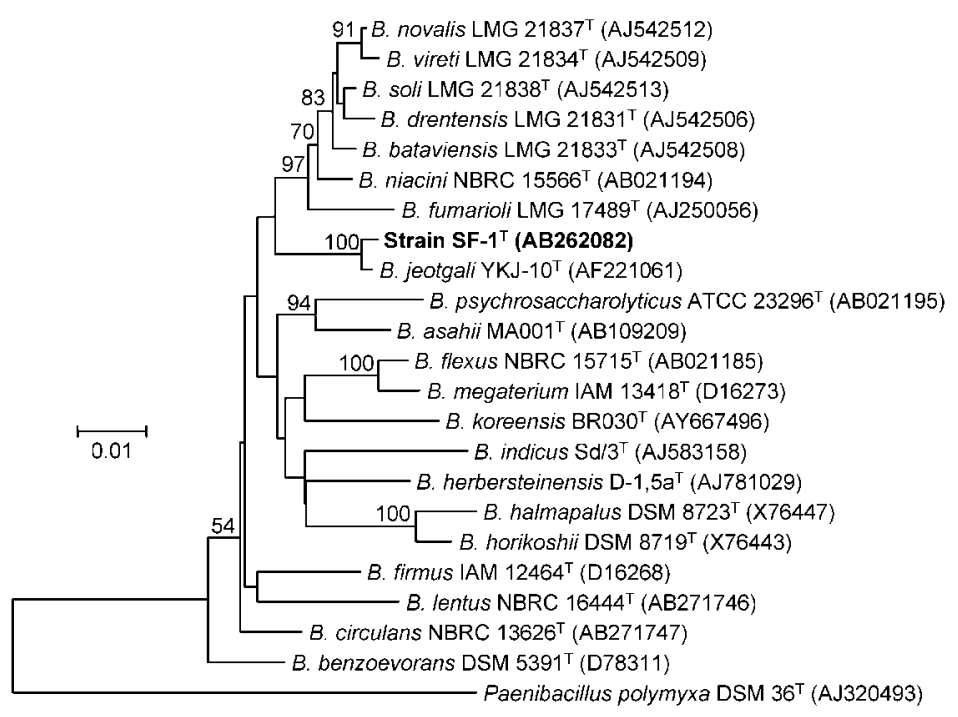

http://ijs.sgmjournals.org
Fig. 1. Neighbour-joining tree derived from $16 S$ rRNA gene sequences showing the relationships between strain $\mathrm{SF}-1^{\top}$ and related Bacillus species. Bootstrap percentages (based on 1000 replications) greater than $50 \%$ are given at branching points. Bar, 0.01 substitutions per nucleotide position. Paenibacillus polymyxa DSM $36^{\top}$ was used as the outgroup to root the tree. Accession numbers are given in parentheses. A maximum-parsimony tree is available as Supplementary Fig. S1 in IJSEM Online. 
Bacillus niacini NBRC $15566^{\mathrm{T}}$ (96.1\%), Bacillus soli LMG $21838^{\mathrm{T}}$ (95.9\%), Bacillus bataviensis LMG $21833^{\mathrm{T}}$ (95.9\%) and Bacillus fumarioli LMG $17489^{\mathrm{T}}(95.5 \%)$.

The optimal $\mathrm{pH}$ for aerobic growth of strain $\mathrm{SF}-1^{\mathrm{T}}$ is 8.0 and the optimal temperature is $40^{\circ} \mathrm{C}$. Strain SF- $1^{\mathrm{T}}$ was able to grow on LB agar plates containing kanamycin $\left(3 \mu \mathrm{g} \mathrm{ml}^{-1}\right)$, tetracycline $\left(3 \mu \mathrm{g} \mathrm{ml}^{-1}\right)$ and chloramphenicol $\left(5 \mu \mathrm{g} \mathrm{ml}^{-1}\right)$, whereas it was highly sensitive to ampicillin and erythromycin. Several other biochemical and physiological characteristics of strain SF- $1^{\mathrm{T}}$ were compared with those of its nearest phylogenetic relative on the basis of $16 \mathrm{~S}$ rRNA gene sequence analysis, $B$. jeotgali JCM $10885^{\mathrm{T}}$ (Table 1). Strain SF $-1^{\mathrm{T}}$ can grow not only aerobically but also anaerobically using selenate, arsenate and nitrate as terminal electron

Table 1. Comparison of phenotypic characteristics between strain SF-1 ${ }^{\top}$ and B. jeotgali JCM $10885^{\top}$

Unless otherwise specified, data for strain $S F-1^{T}$ were obtained from Fujita et al. (1997) and Yamamura et al. (2003) and data for B. jeotgali JCM $10885^{\mathrm{T}}$ were obtained from Yoon et al. (2001) and Imada et al. (2005). +, Positive; -, negative; W, weakly positive. Both strain $\mathrm{SF}-1^{\mathrm{T}}$ and $B$. jeotgali $\mathrm{JCM} 10885^{\mathrm{T}}$ are positive for growth in the presence of 2 and $5 \% \mathrm{NaCl}$, use of oxygen as an electron acceptor, catalase, $\beta$-galactosidase, nitrate reduction, decomposition of starch and acid production from glucose, fructose, aesculin, cellobiose, maltose, sucrose, trehalose, starch, glycogen, gentiobiose and 5-ketogluconate. Both strains are negative for oxidase, formation of indole and acid production from glycerol, erythritol, D-arabinose, L-arabinose, ribose, L-xylose, adonitol, methyl $\beta$-D-xyloside, galactose, mannose, sorbose, rhamnose, dulcitol, inositol, mannitol, sorbitol, methyl $\alpha$-D-mannoside, methyl $\alpha$ D-glucoside, $N$-acetylglucosamine, lactose, melibiose, inulin, melezitose, raffinose, xylitol, D-turanose, D-lyxose, D-tagatose, D-fucose, L-fucose, D-arabitol, L-arabitol, gluconate and 2-ketogluconate.

\begin{tabular}{|lcc|}
\hline Characteristic & $\begin{array}{c}\text { Strain } \\
\text { SF-1 }\end{array}$ & $\begin{array}{c}\text { B. } \text { jeotgali } \\
\text { JCM } \mathbf{~ 1 0 8 8 5}^{\mathbf{T}}\end{array}$ \\
\hline Gram stain & Positive & Variable \\
Temperature range for growth $\left({ }^{\circ} \mathrm{C}\right)$ & $25-40$ & $10-45$ \\
$\mathrm{pH}$ range for growth & $7.5-9.0$ & $7.0-8.0$ \\
$\mathrm{H}_{2} \mathrm{~S}$ production & $+^{*}$ & $-{ }^{*}$ \\
Acid production from: & & \\
D-Xylose & $+^{*}$ & - \\
Arbutin & $+^{*}$ & - \\
Salicin & $+^{*}$ & - \\
Amygdalin & $+^{*}$ & - \\
NaCl tolerance: & & \\
$7 \%$ & - & + \\
$13 \%$ & - & + \\
Electron acceptors: & & $-{ }^{*}$ \\
Selenate & + & $\mathrm{W}^{*}$ \\
Arsenate & + & + \\
Nitrate & + & \\
\hline
\end{tabular}

${ }^{\star}$ Results obtained in this study. acceptors; the selenate is reduced to elemental selenium via selenite, arsenate to arsenite and nitrate to ammonia via nitrite (Fujita et al., 1997; Kashiwa et al., 2000; Yamamura et al., 2003, 2004). B. jeotgali JCM $10885^{\mathrm{T}}$, however, was able to grow with neither selenate nor arsenate as terminal electron acceptors, although nitrate supported weak growth. B. jeotgali JCM $10885^{\mathrm{T}}$ can grow in the presence of $13 \%$ $(\mathrm{w} / \mathrm{v}) \mathrm{NaCl}$, whereas strain SF-1 ${ }^{\mathrm{T}}$ did not grow in the presence of more than $7 \%(\mathrm{w} / \mathrm{v}) \mathrm{NaCl}$. Additionally, strain SF- $1^{\mathrm{T}}$ was positive for acid production from D-xylose, arbutin, salicin and amygdalin, whereas $B$. jeotgali JCM $10885^{\mathrm{T}}$ could not produce acid from these carbon compounds. Production of $\mathrm{H}_{2} \mathrm{~S}$ was also observed only in strain SF- $1^{\mathrm{T}}$. These phenotypic differences seemed to distinguish $\mathrm{SF}-1^{\mathrm{T}}$ from its phylogenetic relative. The cellular fatty acid profile of strain SF-1 $1^{\mathrm{T}}$, in comparison with that of B. jeotgali JCM $10885^{\mathrm{T}}$, is shown in Table 2. The major cellular fatty acid of strain SF- ${ }^{\mathrm{T}}$ was found to be iso- $\mathrm{C}_{15: 0}(47.3 \mathrm{~mol} \%)$, as is the case for B. jeotgali JCM $10885^{\mathrm{T}}$.

Although the $16 \mathrm{~S}$ rRNA gene sequence of strain SF- ${ }^{\mathrm{T}}$ was more than $99 \%$ similar to that of B. jeotgali JCM $10885^{\mathrm{T}}$, the DNA-DNA reassociation value between strain $\mathrm{SF}-1^{\mathrm{T}}$ and $B$. jeotgali JCM $10885^{\mathrm{T}}$ was $14 \%$ (mean from three independent determinations), which is lower than the threshold value (70 \%) recommended for delimiting different species (Wayne et al., 1987). Thus, strain SF-1 ${ }^{\mathrm{T}}$ can be classified as representing a novel species of the genus Bacillus. The DNA G $+\mathrm{C}$ content of strain SF- $1^{\mathrm{T}}(42.8 \mathrm{~mol} \%)$ was comparable to that of B. jeotgali JCM $10885^{\mathrm{T}}$ (41 mol\%) (Yoon et al., 2001).

Table 2. Cellular fatty acid compositions (\%) of strain SF $-1^{\top}$ and $B$. jeotgali JCM $10885^{\top}$

Data for strain SF-1 ${ }^{\mathrm{T}}$ were obtained in this study, whereas data for B. jeotgali JCM $10885^{\mathrm{T}}$ were taken from Yoon et al. (2001).

\begin{tabular}{|c|c|c|}
\hline Fatty acid & Strain $S F-1^{T}$ & B. jeotgali JCM $10885^{\mathrm{T}}$ \\
\hline iso- $\mathrm{C}_{14: 0}$ & 4.5 & 1.9 \\
\hline $\mathrm{C}_{14: 0}$ & 0.6 & 1.3 \\
\hline Summed feature $1^{\star}$ & 1.0 & - \\
\hline iso- $\mathrm{C}_{15: 0}$ & 47.3 & 49.3 \\
\hline anteiso- $\mathrm{C}_{15: 0}$ & 4.2 & 8.8 \\
\hline $\mathrm{C}_{16: 1} \omega 7 c$ alcohol & 8.6 & 4.5 \\
\hline iso- $\mathrm{C}_{16: 1} \mathrm{H}$ & 2.7 & - \\
\hline iso- $\mathrm{C}_{16: 0}$ & 2.9 & 2.3 \\
\hline $\mathrm{C}_{16: 1} \omega 11 c$ & 2.6 & 5.0 \\
\hline $\mathrm{C}_{16: 0}$ & 0.8 & 3.2 \\
\hline iso- $\mathrm{C}_{17: 1} \omega 10 c$ & 10.1 & 7.5 \\
\hline Summed feature $4^{*}$ & 8.7 & 6.6 \\
\hline iso- $\mathrm{C}_{17: 0}$ & 2.6 & 4.1 \\
\hline anteiso- $\mathrm{C}_{17: 0}$ & 1.4 & 3.7 \\
\hline
\end{tabular}

* Summed features represent groups of two or three fatty acids that could not be separated by GC with the MIDI system. Summed feature 1 contained iso- $\mathrm{C}_{15: 1} \mathrm{H}$ and/or $\mathrm{C}_{13: 0} 3-\mathrm{OH}$; summed feature 4 contained anteiso- $\mathrm{C}_{17: 1} \mathrm{~B}$ and/or iso- $\mathrm{C}_{17: 1} \mathrm{I}$. 
The results from biochemical characterizations and DNADNA hybridization strongly indicated that strain $\mathrm{SF}-1^{\mathrm{T}}$ can be distinguished from its closest phylogenetic relative, although they were not differentiated on the basis of cellular fatty acid profiles or $16 \mathrm{~S}$ rRNA gene sequence analysis. Based on the evidence presented above, we describe a novel species within the genus Bacillus, Bacillus selenatarsenatis sp. nov.

\section{Description of Bacillus selenatarsenatis sp. nov.}

Bacillus selenatarsenatis (se'le.nat.ar.se.na'tis. N.L. gen. n. selenatis of selenate; N.L. gen. n. arsenatis of arsenate; N.L. gen. n. selenatarsenatis of selenate and arsenate).

The following description is based on data from this study and from Fujita et al. (1997) and Yamamura et al. (2003). Cells stain Gram-positive and are spore-forming, motile rods $(1 \times 3-6 \mu \mathrm{m})$. Colonies are round and white. Growth occurs at $25-40{ }^{\circ} \mathrm{C}$ and at $\mathrm{pH}$ 7.5-9.0. Growth occurs in the presence of $2-5 \% \mathrm{NaCl}$, but not in the presence of $7 \%$ $\mathrm{NaCl}$. Positive results are obtained for catalase, $\beta$-galactosidase, $\mathrm{H}_{2} \mathrm{~S}$ production and nitrate reduction and negative results are obtained for oxidase, the Voges-Proskauer test, indole production and phenylalanine deamination. Gelatin and starch are hydrolysed. Acid is produced from D-xylose, glucose, fructose, amygdalin, arbutin, aesculin, salicin, cellobiose, maltose, sucrose, trehalose, starch, glycogen, gentiobiose and 5-ketogluconate, but not from glycerol, erythritol, D-arabinose, L-arabinose, ribose, L-xylose, adonitol, methyl $\beta$-D-xyloside, galactose, mannose, sorbose, rhamnose, dulcitol, inositol, mannitol, sorbitol, methyl $\alpha$-Dmannoside, methyl $\alpha$-D-glucoside, $N$-acetylglucosamine, lactose, melibiose, inulin, melezitose, raffinose, xylitol, Dturanose, D-lyxose, D-tagatose, D-fucose, L-fucose, D-arabitol, L-arabitol, gluconate or 2-ketogluconate. Cells are resistant to $3 \mu \mathrm{g}$ kanamycin $\mathrm{ml}^{-1}, 3 \mu \mathrm{g}$ tetracycline $\mathrm{ml}^{-1}$ and $5 \mu \mathrm{g}$ chloramphenicol $\mathrm{ml}^{-1}$, but highly sensitive to ampicillin and erythromycin. The bacterium is a facultative anaerobe that respires oxygen, selenate, arsenate and nitrate as terminal electron acceptors. Selenate is reduced to elemental selenium via the intermediate selenite, arsenate to arsenite and nitrate to ammonia via the intermediate nitrite. The dominant fatty acids are iso- $\mathrm{C}_{15: 0}(47.3 \mathrm{~mol} \%)$, iso- $\mathrm{C}_{17: 1} \omega 10 c \quad(10.1 \mathrm{~mol} \%)$ and $\mathrm{C}_{16: 1} \omega 7 c$ alcohol (8.6 mol\%). The DNA G + C content of the type strain is $42.8 \mathrm{~mol} \%$.

The type strain, SF- $1^{\mathrm{T}}\left(=\mathrm{JCM} 14380^{\mathrm{T}}=\mathrm{DSM} 18680^{\mathrm{T}}\right)$, was isolated from an effluent drain in a glass-manufacturing plant in Japan.

\section{Acknowledgements}

This work was supported by a Grant-in-Aid for Scientific Research (no. 15310056) from the Ministry of Education, Culture, Sports, Science and Technology of Japan. We would like to thank Dr H. Kawasaki and Dr N. Esaki for their assistance with nomenclature and phylogenetic analyses.

\section{References}

Altschul, S. F., Madden, T. L., Schaffer, A. A., Zhang, J., Zhang, Z., Miller, W. \& Lipman, D. J. (1997). Gapped BLAST and PSI-BLAST: a new generation of protein database search programs. Nucleic Acids Res 25, 3389-3402.

Brosius, J., Dull, T. J., Sleeter, D. D. \& Noller, H. F. (1981). Gene organization and primary structure of a ribosomal RNA operon from Escherichia coli. J Mol Biol 148, 107-127.

Ezaki, T., Hashimoto, Y. \& Yabuuchi, E. (1989). Fluorometric deoxyribonucleic acid-deoxyribonucleic acid hybridization in microdilution wells as an alternative to membrane filter hybridization in which radioisotopes are used to determine genetic relatedness among bacterial strains. Int J Syst Bacteriol 39, 224-229.

Felsenstein, J. (1985). Confidence limits on phylogenies: an approach using the bootstrap. Evolution 39, 783-791.

Fujita, M., Ike, M., Nishimoto, S., Takahashi, K. \& Kashiwa, M. (1997). Isolation and characterization of a novel selenate-reducing bacterium, Bacillus sp. SF-1. J Ferment Bioeng 83, 517-522.

Fujita, M., Ike, M., Kashiwa, M., Hashimoto, R. \& Soda, S. (2002). Laboratory-scale continuous reactor for soluble selenium removal using selenate-reducing bacterium, Bacillus sp. SF-1. Biotechnol Bioeng 80, 755-761.

Imada, C., Harada, Y., Kobayashi, T., Hamada-Sato, N. \& Watanabe, E. (2005). Degradation of ferric chelate of ethylenediaminetetraacetic acid by bacterium isolated from deep-sea stalked barnacle. Mar Biotechnol 7, 21-25.

Kashiwa, M., Nishimoto, S., Takahashi, K., Ike, M. \& Fujita, M. (2000). Factors affecting soluble selenium removal by a selenatereducing bacterium Bacillus sp. SF-1. J Biosci Bioeng 89, 528-533.

Katayama-Fujimura, Y., Komatsu, Y., Kuraishi, H. \& Kaneko, T. (1984). Estimation of DNA base composition by high performance liquid chromatography of its nuclease P1 hydrolysate. Agric Biol Chem 48, 3169-3172.

Kawasaki, H., Hoshino, Y., Hirata, A. \& Yamasato, K. (1993). Is intracytoplasmic membrane structure a generic criterion? It does not coincide with phylogenetic interrelationships among phototrophic purple nonsulfur bacteria. Arch Microbiol 160, 358-362.

Kimura, M. (1980). A simple method for estimating evolutionary rates of base substitutions through comparative studies of nucleotide sequences. J Mol Evol 16, 111-120.

Kluge, A. G. \& Farris, F. S. (1969). Quantitative phyletics and the evolution of anurans. Syst Zool 18, 1-32.

Kumar, S., Tamura, K. \& Nei, M. (2004). MEGA3: integrated software for molecular evolutionary genetics analysis and sequence alignment. Brief Bioinform 5, 150-163.

Oremland, R. S. \& Stolz, J. F. (2000). Dissimilatory reduction of selenate and arsenate in nature. In Environmental Microbe-Metal Interactions, pp. 199-224. Edited by D. R. Lovley. Washington, DC: American Society for Microbiology.

Oremland, R. S. \& Stolz, J. F. (2003). The ecology of arsenic. Science 300, 939-944.

Saitou, N. \& Nei, M. (1987). The neighbor-joining method: a new method for reconstructing phylogenetic trees. Mol Biol Evol 4, 406-425.

Stolz, J. F., Basu, P. \& Oremland, R. S. (2002). Microbial transformation of elements: the case of arsenic and selenium. Int Microbiol 5, 201-207.

Thompson, J. D., Gibson, T. J., Plewniak, F., Jeanmougin, F. \& Higgins, D. G. (1997). The CLUSTAL_X windows interface: flexible strategies for multiple sequence alignment aided by quality analysis tools. Nucleic Acids Res 25, 4876-4882. 
Wayne, L. G., Brenner, D. J., Colwell, R. R., Grimont, P. A. D., Kandler, O., Krichevsky, M. I., Moore, L. H., Moore, W. E. C., Murray, R. G. E. \& other authors (1987). International Committee on Systematic Bacteriology. Report of the ad hoc committee on reconciliation of approaches to bacterial systematics. Int J Syst Bacteriol 37, 463-464.

Yamamura, S., Ike, M. \& Fujita, M. (2003). Dissimilatory arsenate reduction by a facultative anaerobe, Bacillus sp. strain SF-1. J Biosci Bioeng 96, 454-460.
Yamamura, S., Terashi, S., Ike, M., Yamashita, M. \& Fujita, M. (2004). Characterization of arsenate-, selenate- and nitrate-reducing activities in Bacillus sp. SF-1. Jpn J Water Treat Biol 40, 161-168.

Yamamura, S., Yamamoto, N., Ike, M. \& Fujita, M. (2005). Arsenic extraction from solid phase using a dissimilatory arsenate-reducing bacterium. J Biosci Bioeng 100, 219-222.

Yoon, J.-H., Kang, S.-S., Lee, K.-C., Kho, Y. H., Choi, S. H., Kang, K. H. \& Park, Y.-H. (2001). Bacillus jeotgali sp. nov., isolated from jeotgal, Korean traditional fermented seafood. Int J Syst Evol Microbiol 51, 1087-1092. 